\title{
Numerical simulation of tsunamis generated by caldera collapse during the 7.3 ka Kikai eruption, Kyushu, Japan
}

\author{
Fukashi Maeno $^{1,2}$, Fumihiko Imamura $^{3}$, and Hiromitsu Taniguchi ${ }^{4}$ \\ ${ }^{1}$ Institute of Mineralogy, Petrology, and Economic Geology, Graduate School of Science, Tohoku University, Aoba, Aoba-ku, \\ Sendai 980-8578, Japan \\ ${ }^{2}$ Earhquake Research Institute, Tokyo University, 1-1-1, Yayoi, Bunkyo-ku, Tokyo 113-0032, Japan \\ ${ }^{3}$ Disaster Control Research Center, Graduate School of Engineering, Tohoku University, Aoba, Aoba-ku, Sendai 980-8579, Japan \\ ${ }^{4}$ Center for Northeast Asian Studies, Tohoku University, Kawauchi, Aoba-ku, Sendai 980-8576, Japan
}

(Received October 27, 2005; Revised April 23, 2006; Accepted April 26, 2006; Online published September 16, 2006)

\begin{abstract}
The relationship between tsunamis and scales of caldera collapse during a 7.3 ka eruption of the Kikai volcano were numerically investigated, and a hypothetical caldera collapse scale was established. Wave height, arrival time, and run-up height and distance were determined at some locations along the coastline around Kikai caldera, using non-linear long-wave equations and caldera collapse models using parameters showing the difference in geometry between pre- and post-collapse and the collapse duration. Whether tsunamis become large and inundations occur in coasts is estimated by the dimensionless collapse speed. Computed tsunamis were then compared with geological characteristics found in coasts. The lack of evidence of tsunami inundation at Nejime, $65 \mathrm{~km}$ from the caldera, suggests that any tsunamis were small; indicating that the upper limit of dimensionless caldera collapse speed was 0.01 . On the other hand, on the coast of the Satsuma Peninsula, $50 \mathrm{~km}$ from the caldera, geological characteristics suggests that tsunamis did not inundate, or that even if tsunamis inundated the area, the traces of a tsunami have been eroded by a climactic pyroclastic flow or the tsunami itself and they have not been left. In numerical computations, when a dimensionless caldera collapse speed is more than 0.003 , tsunami can inundate this area.
\end{abstract}

Key words: Tsunami, caldera-forming eruption, caldera collapse, numerical simulation, Kikai caldera.

\section{Introduction}

Tsunamis generated by caldera-forming eruptions in shallow seas can seriously damage coastal areas (Latter, 1981; Cas and Wright, 1991; Beget, 2000). Following the 1883 eruption of Krakatau, for example, a large tsunami destroyed numerous coastal villages in Java and Sumatra, killing 36,000 people (Simkin and Fiske, 1983; Carey et al., 2000). During the $3.5 \mathrm{ka}$ eruption of Santorini in Greece, the collapse of the volcanic edifice during a catastrophic eruption generated a destructive tsunami (McCoy and Heiken, 2000) that influenced human activities across the eastern Mediterranean (Sullivan, 1988). Previous studies have suggested several scenarios for tsunami generation during caldera-forming eruptions: pyroclastic flows entering the sea (Self and Rampino, 1981; Latter, 1981; Francis, 1985; Siggurdsson et al., 1991; Carey et al., 1996, 2000; McCoy and Heiken, 2000), phreatomagmatic explosion (Yokoyama, 1981, 1987; Nomanbhoy and Satake, 1995), and caldera collapse (Latter, 1981; Siggurdsson et al., 1991). It is likely that the most hazardous tsunamis are those derived from caldera collapse and the resulting sea-level changes that may create more potential energy for tsunami generation than any of the other scenarios. Investigations of the process of tsunami generation, propagation,

Copyright (c) The Society of Geomagnetism and Earth, Planetary and Space Sciences (SGEPSS); The Seismological Society of Japan; The Volcanological Society of Japan; The Geodetic Society of Japan; The Japanese Society for Planetary Sciences; TERRAPUB and inundation as a result of caldera collapse are therefore important. While the infrequent occurrence and violent nature of this type of eruption make it difficult or impossible to directly view all processes of such events and detailed studies are rare, tsunamis can provide useful information to examine the relationship between its wave characteristics and the source parameters (e.g. Nomanbhoy and Satake, 1995; Watts and Waythomas, 2003). Additionally, tsunami deposits, tsunami boulders, or erosional signatures (Bryant, 2001) can also be important clues for revealing the characteristics of tsunamis (Waythomas and Neal, 1998; Minoura et al., 2000; Carey et al., 1996, 2001; Freundt et al., 2006).

The $7.3 \mathrm{ka}$ eruption of Kikai volcano is the most recent and notable caldera-forming eruption in Japan during the Holocene (Machida and Arai, 1978, 2003). The eruption produced ignimbrite and co-ignimbrite ash which devastated prehistoric human settlements of southern Kyushu (Machida and Arai, 1978, 2003). The Volcanic Explosivity Index (VEI) of this eruption was seven, one order of magnitude more than the Krakatau eruption in 1883. The geological evidence for tsunami generation in the $7.3 \mathrm{ka}$ eruption is found in submarine sediments in Tachibana Bay, located on the western coast of Kyushu (Okamura et al., 2005), but the mechanisms and size of tsunami have not yet been studied in detail. This paper describes the results of numerical simulation of the tsunamis generated by the $7.3 \mathrm{ka}$ caldera collapse of the Kikai Caldera, using a simple plunger model. The model results are also compared with geological units 


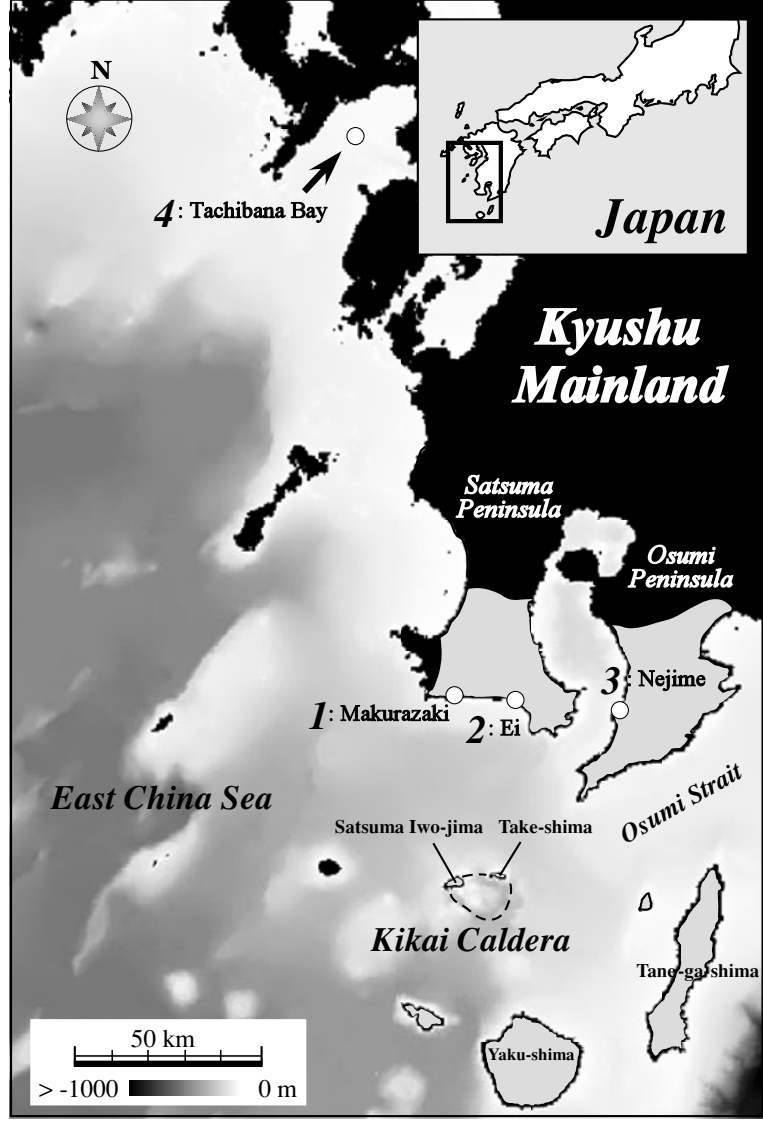

Fig. 1. Location of the Kikai caldera, southwest of Kyushu, Japan. This map also shows the computed area used for the numerical simulations. Tsunami data were collected at four points (1: Makurazaki, 2: Ei, 3: Nejime, and 4: Tachibana Bay). Shaded areas around the Kikai caldera shows the distribution of the Koya-Takeshima ignimbrite.

in the near-field coastal areas, and the scale of caldera collapse during this eruption is discussed. Although other phenomena, such as pyroclastic flow entering sea, are thought to have occurred and could be related to tsunami generation, we focus on the caldera collapse in this paper. This study is the first and preliminary numerical approach to tsunami generation and propagation associated with the 7.3 ka eruption.

\section{Geological Setting and the $\mathbf{7 . 3}$ ka Eruption}

Kikai Caldera, which is $17 \mathrm{~km}$ wide and $20 \mathrm{~km}$ long, is a Quaternary volcano located in the East China Sea, off southern Kyushu, where it forms part of the volcanotectonic depression along the volcanic front of southwestern Japan. Most of the caldera is now submerged except for two main subaerial islands, Take-shima and Satsuma Iwo-jima, which represent the northern caldera rim (Fig. 1). Iwo-dake (a rhyolitic volcano) and Inamura-dake (a basaltic volcano) on Satsuma Iwo-jima represent the tops of submerged postcaldera stratovolcanoes (Ono et al., 1982). The caldera floor is situated 300 to $500 \mathrm{~m}$ below sea level, and shows guidance of a number of submarine cones having subsequently developed.

The 7.3 ka eruption produced four major pyroclastic units, which can be observed on some of the islands surrounding the Kikai caldera, notably Satsuma Iwo-jima and
Take-shima, and on mainland Kyushu (Fig. 1). The lowermost unit is composed of plinian pumice-fall deposits (Funakura pumice-fall), totaling about $20 \mathrm{~km}^{3}$ in volume (Walker et al., 1984). The next unit, intraplinian flows (Funakura ignimbrite), represents less than a few $\mathrm{km}^{3}$, and is followed by $50 \mathrm{~km}^{3}$ of a low-aspect-ratio pyroclastic flow (Koya-Takeshima ignimbrite), traceable up to $80 \mathrm{~km}$ away from the source (Fig. 1; Ui, 1973; Ui et al., 1984). The intraplinian phase and climactic ignimbrite phase were thought to be accompanied with phreatomagmatic explosions (Maeno, 2006; Maeno and Taniguchi, submitted). The topmost layer is composed of more than $100 \mathrm{~km}^{3}$ of co-ignimbrite ash-fall deposits (Akahoya Ash; Machida and Arai, 1978), which are widely dispersed throughout Japan and are of a critical age for understanding the environmental changes associated with postglacial sea-level changes (Arai et al., 1981). The sea level in this area at the time of the eruption was almost the same as at present (Ōki, 2002).

\section{Geometry of the Caldera Pre- and Post-collapse}

The shape of the Kikai caldera after the 7.3 ka eruption is thought to have been a semi-conical pedestal. This geometry is assumed because (1) the conical pedestal model (a 6.5 $\mathrm{km}$ roof radius, $3.9 \mathrm{~km}$ basal radius, and a depth of $2.8 \mathrm{~km}$ with a 47 degree inward dipping angle) is the best match for a large low gravity anomaly and mass deficiency (Ishihara, 1976). (2) Sato and Taniguchi (1997) suggested that the relationship between crater diameter $(R)$ and ejecta volume $(V)$ during phreatomagmatic eruptions is $R=0.97 \times V^{0.36}$. Therefore, from this, the crater diameter can be estimated as from 10 to $15 \mathrm{~km}$ because the ejecta volume was about 170 $\mathrm{km}^{3}$ (Machida and Arai, 2003), corresponding to a Dense Rock Equivalent (DRE) of about $85 \mathrm{~km}^{3}$. It is widely believed that the volume of caldera collapse is within the same order as the total volume of magma erupted (e.g. Marti et al., 1994). Here, we assumed that, in the case of maximum collapse, the chamber of $85 \mathrm{~km}^{3}$ collapsed completely and the topmost part, $15 \times 10 \mathrm{~km}$ wide, the same as the present caldera width, fell to a depth of $700 \mathrm{~m}\left[=85 \mathrm{~km}^{3} /(15 \mathrm{~km} / 2\right.$ $\times 10 \mathrm{~km} / 2 \times \pi)]$.

The pre-eruptive form is thought to have been a semicone with a base of about $15 \times 10 \mathrm{~km}$ and a maximum height of $800 \mathrm{~m}$ for the following reasons: (1) the KikaiKomoriko tephra group on the two islands representing the caldera rim, which is derived from intermittent volcanic activity between 13 to $8 \mathrm{ka}$ (Okuno et al., 2000), indicates that a subaerial volcano was present in the Kikai caldera just before the $7.3 \mathrm{ka}$ eruption. (2) The deepest floor of the present-day caldera is about $500 \mathrm{~m}$ deep, $200 \mathrm{~m}$ shallower than the estimated maximum collapse depth $(-700 \mathrm{~m})$, indicating depositing of about $25 \mathrm{~km}^{3}$ of volcanic debris on the original caldera floor. We assumed that the material deposited on the caldera floor is landslide breccia probably derived from the caldera rim during collapse. The volume of $25 \mathrm{~km}^{3}$ corresponds to a semi-cone with a base of about $15 \times 10 \mathrm{~km}$ and a height of $800 \mathrm{~m}$.

\section{Modeling of Caldera Collapse Process}

Collapse models were used to determine the difference between pre- and post-collapse geometry and the duration 

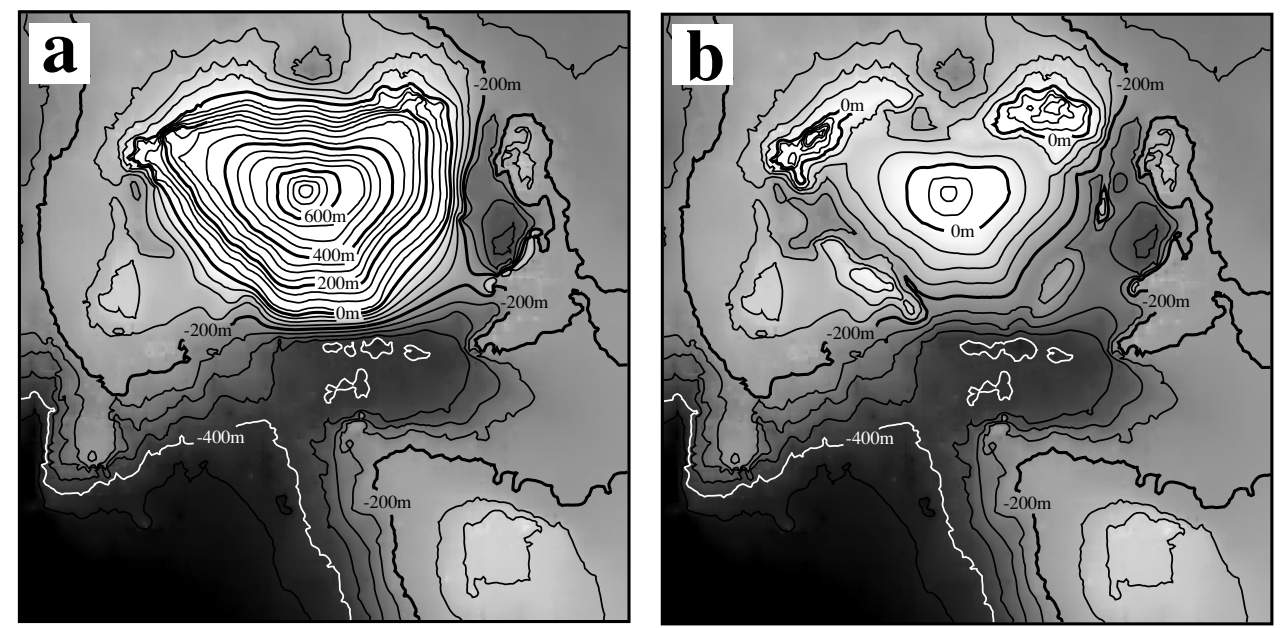

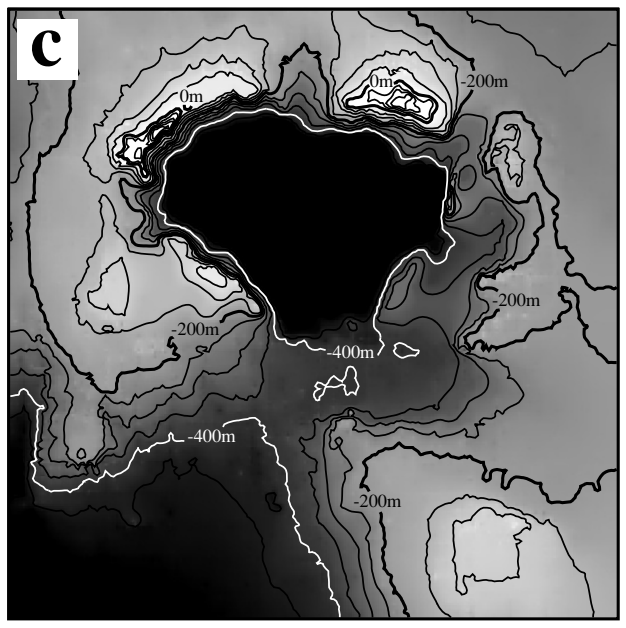

$>\mathbf{0} \mathbf{m}$

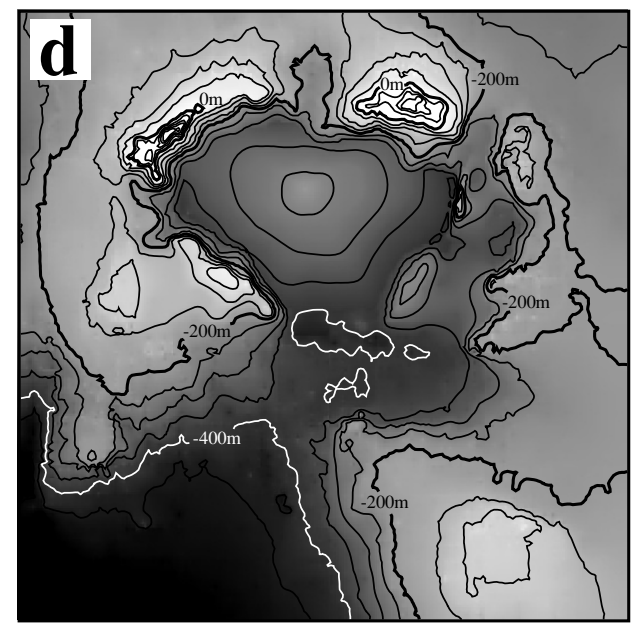

$10 \mathrm{~km}$

Fig. 2. The topographical data used for numerical calculations. (a) and (b) show estimated pre-eruptive geometries of Kikai caldera; heights of 800 and $120 \mathrm{~m}$, respectively. (c) and (d) show estimated post-eruptive geometries; 500 and $250 \mathrm{~m}$ deep, respectively. The contour is $50 \mathrm{~m}$.

of collapse. The collapse model showing the largest geometrical change is a conical stratocone with a base of 15 $\times 10 \mathrm{~km}$ and a height of $800 \mathrm{~m}$, collapse to a depth of $500 \mathrm{~m}$ (model 1; Figs. 2(a) and (c)). Other collapse models were examined using a combination of geometrical preand post-collapse models as follows: an island of $120 \mathrm{~m}$ collapsed to $-500 \mathrm{~m}$ (model 2; Figs. 2(b) and (c)), an island of $800 \mathrm{~m}$ collapsed to $-250 \mathrm{~m}$ (model 3; Figs. 2(a) and (d)), and an island of $120 \mathrm{~m}$ collapsed to $-250 \mathrm{~m}$ (model 4; Figs. 2(b) and (d)). The duration of caldera collapse is not well known. Wilson and Hildreth (1997) estimated that the collapse of the Long Valley caldera $(30 \times 15 \mathrm{~km})$ took approximately 98 hours, while the caldera-forming eruption of Pinatubo (2.5 km in diameter) in 1991 lasted approximately 9 hours (Wolfe and Hoblitt, 1996). Lavallee et al. (2004) used a mean value of 17 hours based on scaling their analog experiments. It is possible that the collapse of the Krakatau caldera associated with the 1883 eruption occurred in only a few hours (Verbeek, 1885). In this study, collapse durations of 8-16 sec at free fall (Eq. (1)), and 300, $600,1200,2400 \mathrm{sec}, 1,2,6$, and $12 \mathrm{~h}$, respectively, at a uniform velocity (Eq. (2)) were used for all collapse models (Table 1). Geometrical changes were introduced using the following equations of free fall and uniform velocity, respectively:

$$
\begin{gathered}
h(t)=h_{\text {before }}-\left\{\frac{h_{\text {before }}-h_{\text {after }}}{t_{s}} t\right\}, \\
h(t)=h_{\text {before }}-\frac{1}{2} g t^{2},
\end{gathered}
$$

where $h(t)$ is the time-dependent still water depth in the collapsed area, $h_{\text {before }}$ and $h_{\text {after }}$ are the constant still water depths before and after caldera collapse, respectively, $t$ is time, $t_{s}$ is the duration of collapse, and $g$ is the gravitational acceleration. The free-fall source has a time limitation: $t<t_{s}$.

\section{Numerical Model of Tsunami}

Numerical computations of the tsunamis generated with each collapse model were calculated, according to the shallow water theory, which includes bottom friction (Shuto et $a l ., 1990)$, taking into account the effect of inundation. The average depth of the simulated area is about $200 \mathrm{~m}$; therefore, for practical purposes, non-linear long wave equations were deemed most suitable. Gray and Monaghan (2003) 
Table 1. Caldera collapse models and numerical conditions for tsunami simulation of the 7.3 ka eruption

\begin{tabular}{|c|c|c|c|c|c|c|c|c|c|}
\hline \multirow{3}{*}{$\begin{array}{l}\text { Caldera collapse- } \\
\text { model (unit: m) }\end{array}$} & \multicolumn{9}{|c|}{ Durations of caldera collapse } \\
\hline & \multirow{2}{*}{$\begin{array}{l}\text { Free fall } \\
10-20 \mathrm{~s}\end{array}$} & \multicolumn{8}{|c|}{ Uniform velocity } \\
\hline & & $300 \mathrm{~s}$ & $600 \mathrm{~s}$ & $1200 \mathrm{~s}$ & $2400 \mathrm{~s}$ & $1 \mathrm{~h}$ & $2 \mathrm{~h}$ & $6 \mathrm{~h}$ & $12 \mathrm{~h}$ \\
\hline (a) $+800 \rightarrow$ (d) -500 & $\operatorname{model} 1_{F F}$ & model $1_{300}$ & $\operatorname{model} 1_{600}$ & model $1_{1200}$ & model $1_{2400}$ & $\operatorname{model} 1_{1 h}$ & $\operatorname{model} 1_{2 h}$ & model $1_{6 h}$ & model $1_{12 h}$ \\
\hline (b) $+120 \rightarrow(d)-500$ & model $2_{F F}$ & model 2300 & model 2600 & model $2_{1200}$ & model 22400 & model $2_{1 h}$ & model $2 h$ & $\operatorname{model} 2_{6 h}$ & model $2_{12 h}$ \\
\hline (a) $+800 \rightarrow(c)-250$ & model $3_{F F}$ & model $3_{300}$ & model3 600 & model $_{1200}$ & model 32400 & model $3_{1 h}$ & model $_{2 h}$ & model $3_{6 h}$ & model $_{12 h}$ \\
\hline (b) $+120 \rightarrow(c)-250$ & model $4_{F F}$ & model 4300 & model 4600 & model $4_{1200}$ & model $4_{2400}$ & model $_{1 h}$ & model $4_{2 h}$ & model $_{6 h}$ & model $4_{12 h}$ \\
\hline Calculation time & $2 h$ & $2 h$ & $2 h$ & $2 h$ & $2 h$ & $2 h$ & $2 h$ & $8 h$ & $14 h$ \\
\hline
\end{tabular}

used a smooth particle hydrodynamic theory in combination with laboratory experiments to investigate the waves produced by the collapse of a caldera connected to the sea. They mainly paid attention to the source problem, using cavity parameters, and did not consider the inundation process on coastal areas. On the other hand, we used the nonlinear shallow water wave approach, which is a more appreciable methodology for tsunami generation and propagation from near- to far-field smoothly, taking inundation on coasts around a volcano into consideration. The following nonlinear long-wave equations were used:

$$
\begin{gathered}
\frac{\partial(\eta-h)}{\partial t}+\frac{\partial M}{\partial x}+\frac{\partial N}{\partial y}=0, \\
\frac{\partial M}{\partial t}+\frac{\partial}{\partial x}\left(\frac{M^{2}}{D}\right)+\frac{\partial}{\partial y}\left(\frac{M N}{D}\right)+ \\
g D \frac{\partial \eta}{\partial x}+\frac{g n^{2}}{D^{\frac{7}{3}}} M \sqrt{M^{2}+N^{2}}=0, \\
\frac{\partial N}{\partial t}+\frac{\partial}{\partial x}\left(\frac{M N}{D}\right)+\frac{\partial}{\partial y}\left(\frac{N^{2}}{D}\right)+ \\
g D \frac{\partial \eta}{\partial y}+\frac{g n^{2}}{D^{\frac{7}{3}}} N \sqrt{M^{2}+N^{2}}=0 .
\end{gathered}
$$

For far-field from the caldera, Eq. (3) can be rewritten as

$$
\frac{\partial \eta}{\partial t}+\frac{\partial M}{\partial x}+\frac{\partial N}{\partial y}=0
$$

where $\eta$ is the water surface elevation, $D=(\eta+h)$ is the total depth, $M$ and $N$ are the water flux per unit width in $x$ and $y$-directions, respectively, and $n$ is the Manning roughness coefficient $(=0.025)$. This value of the Manning coefficient is widely used in numerical simulation of tsunami (Shuto et al., 1990). We also introduced the following artificial viscosity (Goto and Shuto, 1980) into the continuous equation to control numerical instability:

$$
\beta\left(\Delta x^{3}\right) \sqrt{\frac{g}{D}}\left|\frac{\partial^{2} \eta}{\partial x^{2}}\right| \frac{\partial^{2} \eta}{\partial x^{2}},
$$

where $\beta$ is the constant (1.2).
In numerical computations using shallow water equations, neither the calculated wave amplitude nor the velocity becomes large enough to cause numerical instability. Therefore, the differences in numerical results between a shallow water model and a full Navier-Stokes model are not great (e.g. Aoki et al., 1997; Matsui et al., 2002). In addition, phenomenally, wave amplitude calculated from a full Navier-Stokes model may be larger than that calculated from a shallow water model around the place where water waves meet or collide. This is due to a larger vertical acceleration of water in a full Navier-Stokes model. However, the waveforms of tsunamis around the caldera in this case are not very different between the two models since wavebreaking should occur in a full Navier-Stokes calculation and the short wave-component should disappear.

\section{Conditions of Numerical Calculation}

Numerical calculations of the tsunamis were conducted using bathymetric data to estimate the wave heights and forms, arrival times, and run-up heights and distances at three locations on the southern coast of Kyushu mainland and Tachibana Bay (Fig. 1). In the computations, the nonlinear long-wave equations were discretized using the stag-

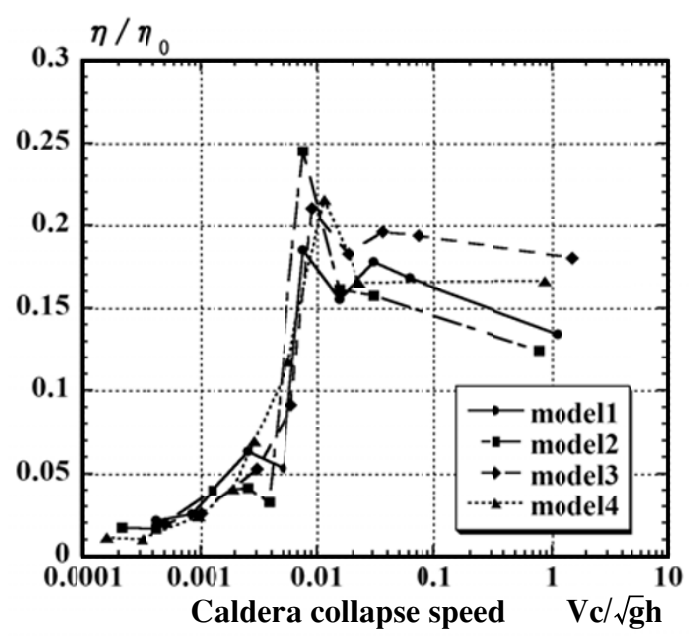

Fig. 3. Numerical results for the relationship between the dimensionless collapse speed $\left(\mathrm{V}_{c} / \sqrt{g h}\right)$ and dimensionless maximum height $\left(\eta / \eta_{0}\right)$ north of the caldera. $\eta_{0}$ is the maximum height of the tsunami in the north of caldera with $200 \mathrm{~m}$ depth for free fall conditions. The maximum height of the tsunami was largest when $\mathrm{V}_{c} / \sqrt{g h}$ was about 0.01 in all models. 


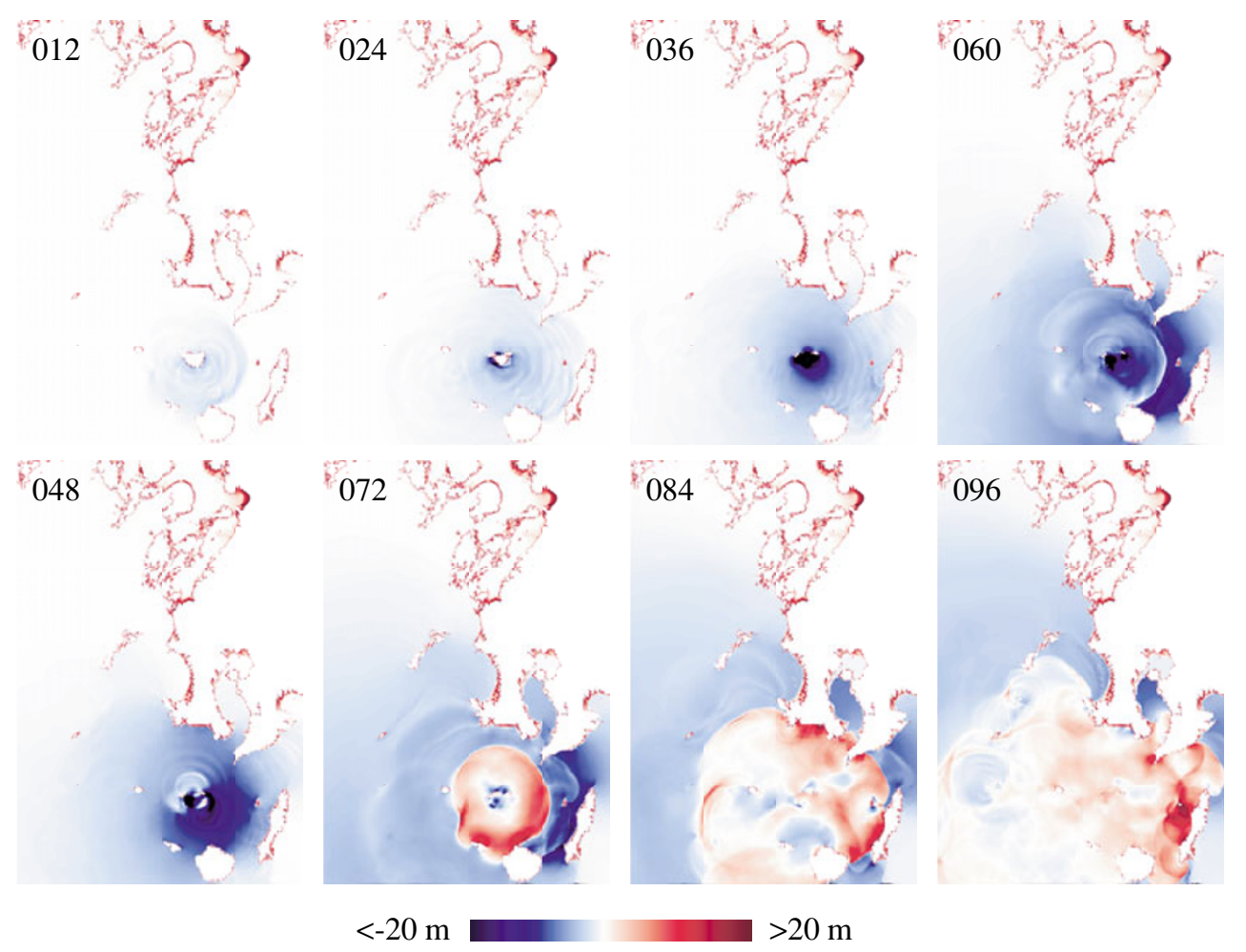

Fig. 4. Results of numerical calculations of tsunami by a caldera collapse, using model 1 with 1 hour collapse-duration. An upper left number in each figure shows a time from collapse starting.

gered leap-frog scheme with a truncation error of the second order (Goto and Ogawa, 1992). Pre- and post-eruptive bathymetric and geographical data at the caldera were derived by digitizing the topographic map. A time interval, $\Delta t$, is $0.5 \mathrm{~s}$ was used. Other data in the computational domain, $\Delta x$, was obtained from interpolating twodimensional random data on regular grid system, using a $450 \mathrm{~m}$ mesh bathymetric data of JODC (Japan Oceanographic Data Center) and a $50 \mathrm{~m}$ mesh altitude data of GSI (Geographical Survey Institute of Japan). In calculations for near-field (southern coasts of Kyushu mainland and other near-caldera islands), a $150 \mathrm{~m}$ grid is used. On the other hand, in calculations for the more distant site (Tachibana Bay), a $450 \mathrm{~m}$ grid system is used. Effects of grid-size differences between 150 and $450 \mathrm{~m}$ grid calculations on tsunami waveforms are small in their generation and propagation processes, but are large in their inundation process (run-up distance and run-up height). Therefore, run-up distance and run-up height of tsunamis at nearfield coastal areas were evaluated using only the $150 \mathrm{~m}$ grid calculations. Results of $450 \mathrm{~m}$ grid calculation are used for evaluations of tsunami propagation processes at far-field from the source, as Tachibana Bay. The appropriate stability criterion, as the Courant, Friedrichs, and Lewy (CFL) condition, $\Delta t<\Delta x / \sqrt{g h_{\max }}$, was used in the calculations to determine the time step for the grid size, following Goto and Ogawa (1992). During the simulations, computed sea levels were determined at 6 min intervals for the entire grid mesh. All parameter studies for different calderas collapse models and calculation conditions are shown in Table 1.

\section{Results and Discussion}

\subsection{Generation and propagation of tsunamis}

Results of the numerical computations calculated from the relationship between the depth and duration of the collapse with each model showed that the maximum height of the tsunami near the caldera varies. Figure 3 shows the relationship between the maximum height of the tsunami $(\eta)$ north of the caldera and the collapse speed $\left(\mathrm{V}_{c}\right)$ with all models. The horizontal axis shows the dimensionless collapse speed $\left(\mathrm{V}_{c} / \sqrt{g h}\right)$, and the vertical axis illustrates the dimensionless maximum height of the tsunami $\left(\eta / \eta_{0}\right) . \eta_{0}$ is the maximum height of the tsunami in the north of caldera with $200 \mathrm{~m}$ depth for free-fall conditions. The computed maximum height of the tsunami north of the caldera was largest when the dimensionless collapse speed $\left(\mathrm{V}_{c} / \sqrt{g h}\right)$ was about 0.01 for all models, and the height substantially decreased with slower speeds (longer collapse durations). In all models, just after collapse began, the sea level rapidly fell due to the flow of seawater into the void formed by the collapse. It then gradually recovered and started to ascend, because water waves entered the collapsed area, collided and the total wave height increased, resulting in a large water wave. The amount of seawater displaced into the collapsed area is given by the product of the sea depth, $h$, and velocity of seawater, $u$ or $v$, which is given by $\sqrt{g h}$ based on the long wave theory; the amount of seawater was shown to be proportional to $h^{3 / 2}$. When the collapse speed was high, the sea level rose rapidly, and a large tsunami was generated, because the large amount of seawater flowed into the collapsed area in a short time and the wave crest easily became higher than the original sea surface. However, during free-fall conditions, lower wave crests appeared than in 


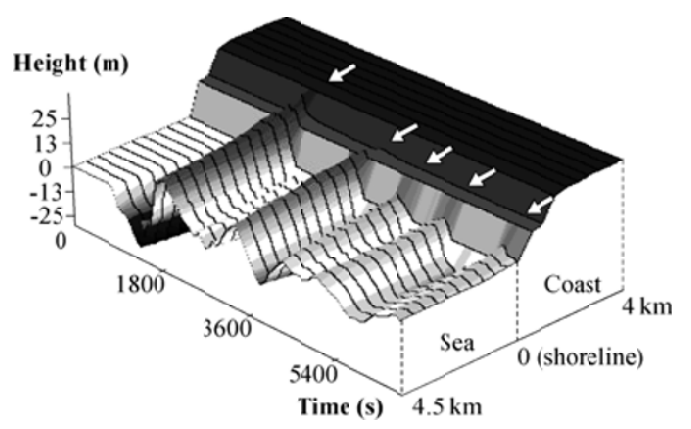

Fig. 5. Numerical results showing a set of sea level time-histories taken along a transect along the coast at Ei for model 1 (free fall). The first positive peak of $30 \mathrm{~m}$ inundated $1.5 \mathrm{~km}$ inland within $30 \mathrm{~min}$ after caldera subsidence started followed by a number of positive peaks. Arrows show the positive peaks.

cases of slightly longer duration models (600 or $1200 \mathrm{sec}$ ) and the wave didn't reach the maximum height. This is because a brief collapse duration could produce the deeper wave-collision level, resulting in a wave that was unable to go out of the collapsed space, even if the wave amplitude was large (as model 1 under free fall condition). On the other hand, when the collapse speed was slightly slower than the free-fall condition, the maximum height of the tsunami increased because the wave-collision level could be shallower, allowing the crest of the wave to heighten on the sea surface (as model 12400 sec' duration). These results indicate that the maximum height of the tsunami near the caldera varies depending on the relationship between the collapse depth and velocity of sea-water. The largest tsunami was generated when the speed of collapse $\left(\mathrm{V}_{c} / \sqrt{g h}\right)$ was about 0.01 .

The tsunami generated by caldera collapse is thought to have spread almost circularly from the Kikai caldera. Numerical results using model 1 with $1 \mathrm{~h}$ collapse-duration are shown in Fig. 4, where the first negative peak reached Yaku-shima within 20 min, Satsuma Peninsula within 30 min, and Tane-ga-shima within 40 min while the first positive peak reached all locations approximately $50 \mathrm{~min}$ after the first negative peak. Figure 4 shows the results after $96 \mathrm{~min}$. In Tachibana Bay (location 4), the first negative peak reached the Kyushu mainland within $1.4 \mathrm{~h}$ and the first positive wave reached land within $3.4 \mathrm{~h}$. A typical waveform therefore shows a negative peak followed by positive peaks (Fig. 5). Although the computed tsunami showed differences in maximum heights and arrival times with each model, there were no significant differences in the shape of the waveforms with different collapse durations. In Tachibana Bay, the wave height is about $6 \mathrm{~m}$, even in a maximum case (Fig. 6), which may be an effect of the shallower sea floor in the distal region, especially north of the calculated area.

\subsection{Inundation of tsunamis in coastal area}

The maximum height of a tsunami and the factors controlling whether inundation occurs in coastal areas is determined by the initial conditions, except in the far-field where characteristics become less sensitive to the generation mechanisms. In three locations along the coast of the Kyushu mainland, the maximum heights of tsunamis are calculated for all models in which multiple waves produce run-up on land. For example, at Makurazaki (loca-
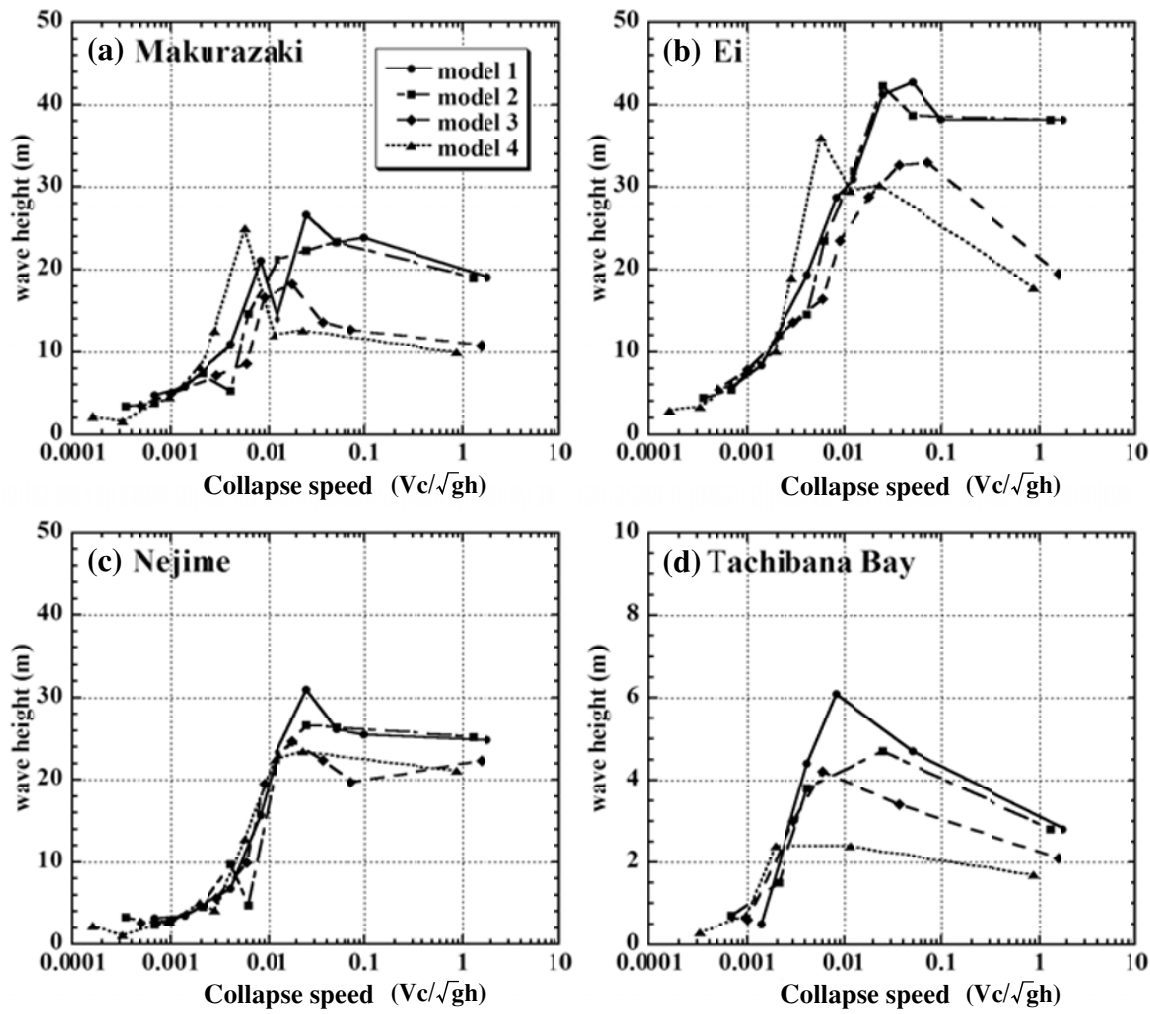

Fig. 6. Computed maximum tsunami heights in relation to caldera collapse speed at Makurazaki (a), Ei (b), Nejime (c), and Tachibana Bay (d) with all collapse models. 

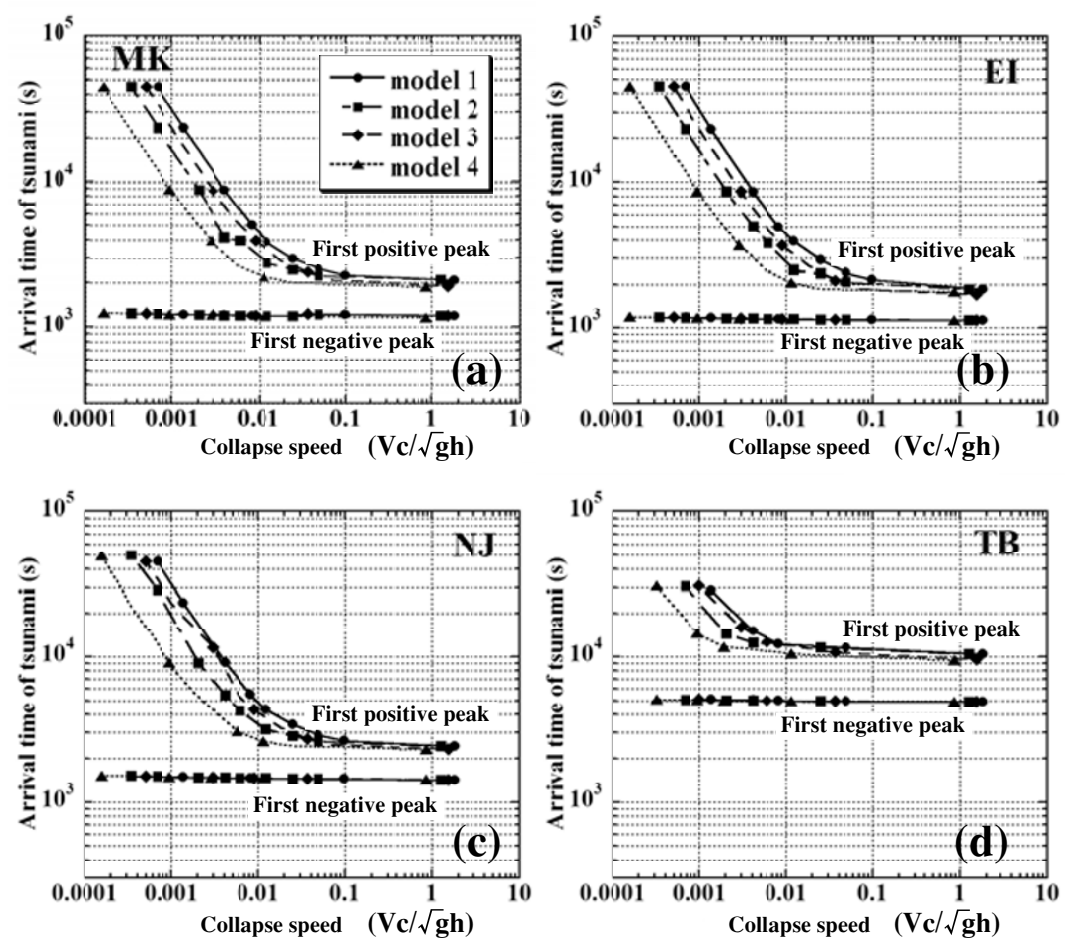

Fig. 7. Arrival times of the tsunami in relation to collapse speed at Makurazaki (a), Ei (b), Nejime (c), and Tachibana Bay (d) for all collapse models. In each figures, lower horizontal lines show first negative peaks, which were not dependent on collapse speed, and the upper curved lines show positive run-up peaks, which were dependent on collapse speed. Slower the collapse speed, the later the arrival time.

tion 1 in Fig. 1) and Ei (location 2) on the southern coast of the Satsuma Peninsula, the numerical models indicates that the primary wave extended about $1.5 \mathrm{~km}$ inland and had a maximum height of more than $30 \mathrm{~m}$ for the free fall conditions of model 1 (Figs. 5 and 6). When the collapse speed was slowed, the tsunami height was just a few meters and it did not occur in most coastal areas. The model results showed that when the dimensionless caldera collapse speed was more than 0.003 , the computed tsunamis could inundate areas about $30 \mathrm{~m}$ in elevation at southern coasts of Satsuma Peninsula where we surveyed the deposits (see Section 7.3). Although the arrival time of the first negative peak of the computed tsunamis was the same for all models, those of the first positive run-up peaks varied between models, depending on the collapse duration (Fig. 7).

\subsection{Geological characteristic in coastal areas}

Deposits from the $7.3 \mathrm{ka}$ eruption are distributed widely along the southern Kyushu mainland. We conducted a survey from Makurazaki to Ei (locations A-G in Fig. 8) along the southern coast of Satsuma Peninsula, $50 \mathrm{~km}$ from the caldera, and at Nejime (location H in Fig. 8) on the western coast and another location inland (location I in Fig. 8) of the Osumi Peninsula, $65 \mathrm{~km}$ from the caldera. The sites were distributed less than about $1 \mathrm{~km}$ from the shoreline at about $30 \mathrm{~m}$ in elevation (locations $\mathrm{A}-\mathrm{F}$ and $\mathrm{H}$ ) and $4-5 \mathrm{~km}$ from the shoreline at 100-200 $\mathrm{m}$ in elevation (locations $\mathrm{G}$ and I).

In coastal areas from Makurazaki to $\mathrm{Ei}$, the eruptive deposits are Koya-Takeshima ignimbrite that is composed of three sub-units, a basal ground layer and massive pumiceous main body, accompanied by minor amounts of co-ignimbrite ash in the topmost layer. At almost all locations (locations A-F), the ignimbrite occurs on the erosional surface of the pre-existing Ito ignimbrite (Aramaki, 1984) or other non-volcanic sediments. In addition, the main body of ignimbrite is sometimes eroded, and the deposit is sometimes composed only of a basal lithic-rich breccia and underlies channel-like depressions (location C). A notable characteristic in this area is the lack of pumice fallout deposits derived from the first stage of this eruption. And, the stratigraphy of other outcrops (locations G, H, and I) is characterized by the pumice fallout deposits, KoyaTakeshima ignimbrite, and co-ignimbrite ash-fall deposits without erosional surfaces. Furthermore, typical tsunami deposits, such as shell fragments, diatoms, or foraminifera (Dawson and Shi, 2000), and other traces of tsunami inundation, such as tsunami boulder deposits or erosional signatures (Bryant, 2001), are not observed in any sections.

On the Nejime coast, a vertical sequence of the $7.3 \mathrm{ka}$ deposits ( $40 \mathrm{~cm}$ thickness) can be found at $20 \mathrm{~m}$ in elevation (location $\mathrm{H}$ ), and it is characterized by plinian fallout, KoyaTakeshima ignimbrite, and co-ignimbrite ash fall deposits. Any tsunami traces, such as erosional surfaces or tsunami deposits, can not be observed at all at the studied site, and the lower level (0-20 m in elevation) is characterized by only bed sediments with a slope.

\subsection{Interpretation of tsunami traces in each coastal locations}

On the southern coast of the Satsuma Peninsula (from Makurazaki to Ei), the culminating pyroclastic flow lies directly on the erosion surface, which is a typical lithofacies of this area. The ignimbrites can be interpreted to have been deposited from a flow that was relatively dilute and stratified, with lower, denser, lithic-rich layers and upper, expanded, pumice-rich layers, which is generally accom- 

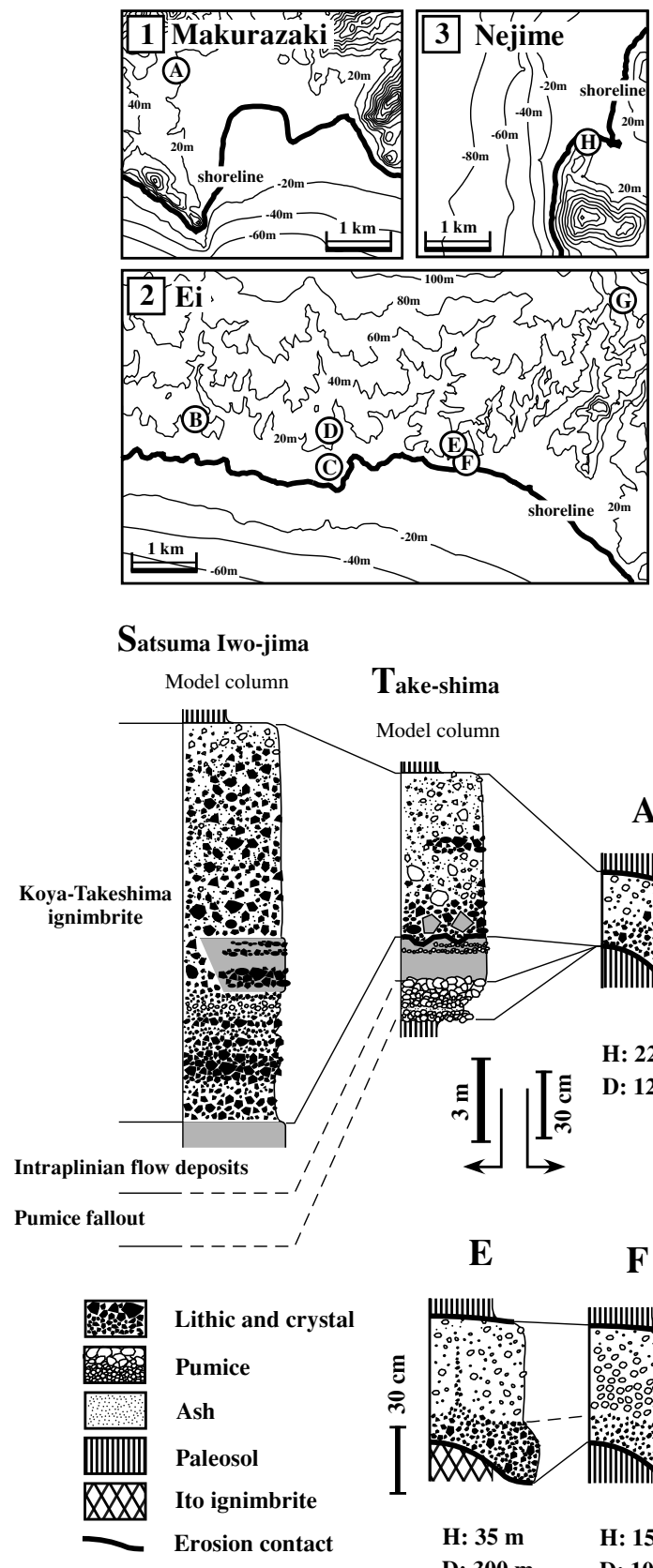

Take-shima Model column

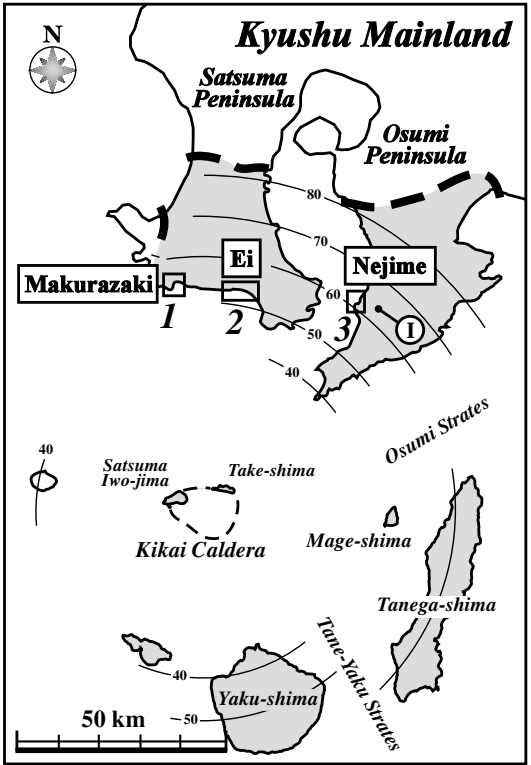

A

B

D

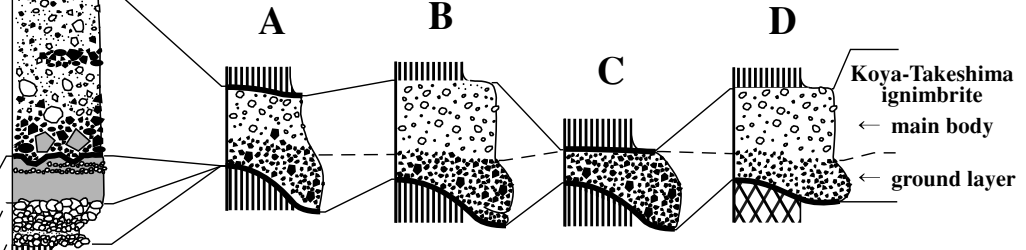

\begin{tabular}{lllll} 
& H: $22 \mathrm{~m}$ & H: $22 \mathrm{~m}$ & H: $12 \mathrm{~m}$ & H: $22 \mathrm{~m}$ \\
\hline & D: $\mathbf{1 2 5 0 \mathrm { m }}$ & D: $\mathbf{5 0 0} \mathrm{m}$ & D: $300 \mathrm{~m}$ & D: $500 \mathrm{~m}$
\end{tabular}

$\stackrel{+}{\longrightarrow}$

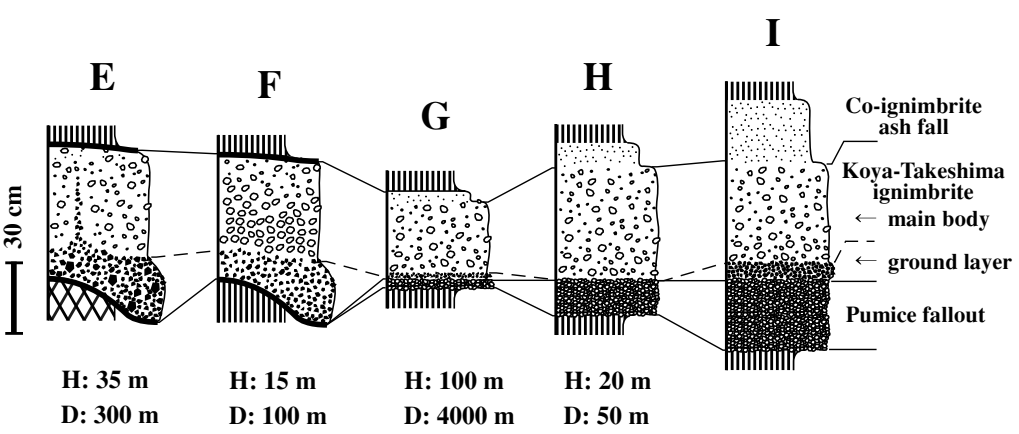

H: height of outcrop, D: distance from shoreline

Fig. 8. Columnar sections of the outcrops in coastal areas of Satsuma (1: Makurazaki, 2: Ei) and Osumi Peninsula (3: Nejime, location I). Locations of the 8 sections examined (A-H) are shown in detail in the upper left figures. $\mathrm{H}$ and D show the altitude and distance from the shoreline, respectively. Model proximal sections in Satsuma Iwo-jima and Take-shima are also shown. Column I shows the typical inland section in Osumi Peninsula (the location is shown in the upper right figure). Shaded areas in the upper right figure shows the distribution of the Koya-Takeshima ignimbrite.

panied by large voluminous ignimbrites (e.g. Freundt and Schminke, 1985). On the basis of the geological units, the critical timing of tsunami arrival cannot be constrained, but three possible explanations for the inundation process are suggested: (1) Tsunamis inundated the area (more than $15 \mathrm{~m}$ in height) before the arrival of pyroclastic flow, and tsunami deposits and pumice fallout associated within the first stage were eroded by the just-deposited pyroclastic flow with substrates shearing. A lack of pumice fall deposits is reported in the 1883 Krakatau eruption (Carey et al., 1996). One of reasons for the lack of recognizable fall deposits in Krakatau may be the result of erosion of fall de- posits by subsequent pyroclastic flow and surges (Carey et al., 1996). The erosional surfaces on underlying welded tuff of Funakura ignimbrite (intraplinian flow deposits) at Takeshima (see model column in Fig. 8) also indicate strong shearing in the base of the climactic pyroclstic flow. In the proximal area, the first pumice fall is covered by the overlying welded Funakura ignimbrite. (2) Tsunamis inundated the area before or after pyroclastic flow but tsunami deposits or other traces of tsunami inundation were not left, because a steep slope or nearshore flat beaches allowed the tsunami to erode the original surface (Nishimura and Miyaji, 1995; Gelfenbaum and Jaffe, 2003). In addition, most coasts are 


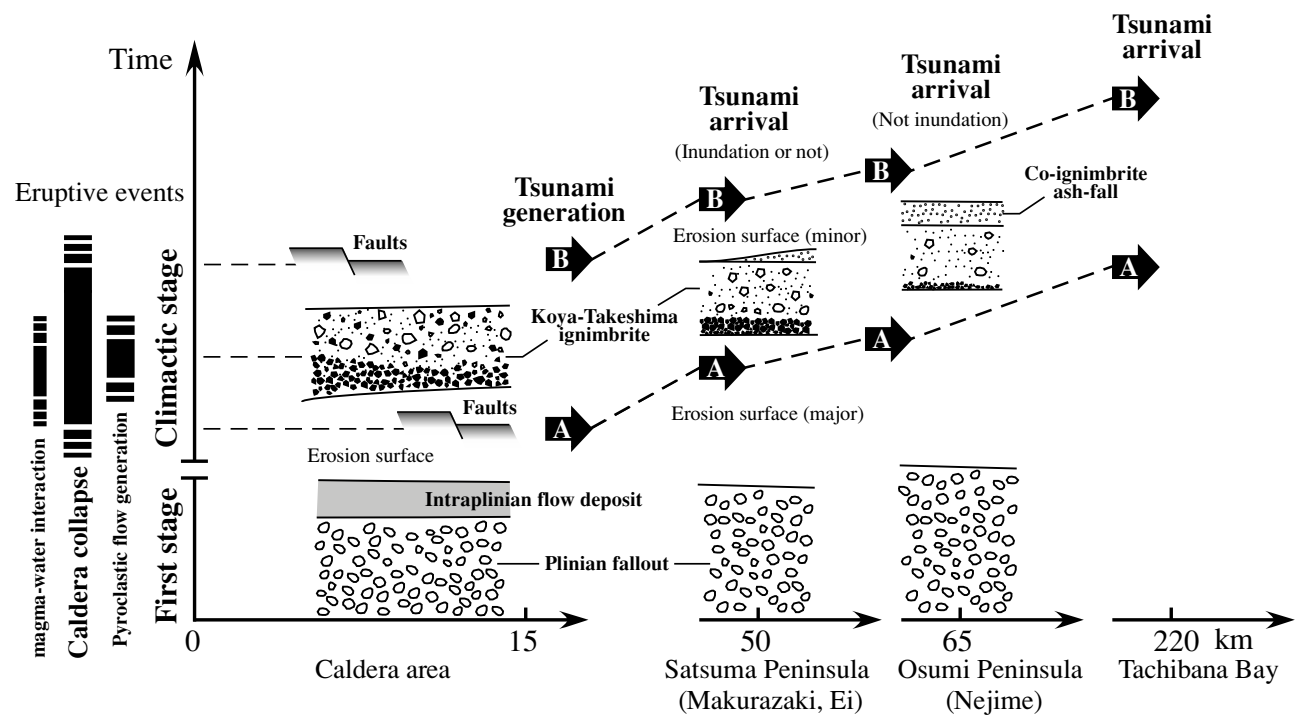

Fig. 9. Schematic time-distance plot of 7.3 ka eruptive events. Caldera collapse seems to have occurred before a climactic pyroclastic flow eruption, and this event possibly has continued until the end of the pyroclastic flow deposition, based on faults distributions (Satsuma Iwo-jima, Kawanabe and Saito, 2002; Take-shima, Maeno, 2006; Maeno and Taniguchi, submitted). The source was presumably submerged and the vent was located in shallow water, while the voluminous pyroclastic flow was produced. Tsunamis may have been generated and propagated before or after the climactic pyroclstic flow generation (arrows A and B).

mainly composed of older welded tuff such as Ata ignimbrite (Aramaki and Ui, 1966) or lava flows and there are few beaches or coral reef, indicating that tsunamis did not have supplies of beach sand or coral fragments inland of this area. (3) No tsunami inundation occurred in the area we surveyed.

On the Nejime coast, geological features suggest that the maximum tsunami run-up (inundation) height was not over $20 \mathrm{~m}$ in elevation because any tsunami traces cannot be observed at the studied elevation. This geologic observation does not deny that tsunami inundated the areas at less than $20 \mathrm{~m}$ in elevation; that is, the $0-20 \mathrm{~m}$ elevation shows a possible tsunami inundation level.

\subsection{Implication for the caldera collapse process during the 7.3 ka eruption}

Caldera collapse in the $7.3 \mathrm{ka}$ eruption seems to have occurred before a climactic pyroclastic flow eruption, and this event possibly has continued until the end of the pyroclastic flow deposition, based on faults distributions (Satsuma Iwo-jima, Kawanabe and Saito, 2002; Take-shima, Maeno, 2006; Maeno and Taniguchi, submitted) (Fig. 9). In the base of the Koya-Takeshima ignimbrite in Satsuma Iwojima, poorly vesicular obsidian clasts, bombs with chilled cracks, and boulders are included. In addition, in southern Kyushu, there are armored lapilli and accretionary lapilli concentrated at the base of co-ignimbrite ash-fall deposits (Machida and Arai, 1978). This evidence indicates that magma-water interactions have occurred during the climactic pyroclastic flow phase (Maeno, 2006) (Fig. 9), and the source was, therefore, presumably submerged and the vent was located in shallow water, while the eruption rates reached its highest level and a voluminous pyroclastic flow was produced. Tsunamis may have been generated and propagated before or after the climactic pyroclastic flow generation (arrows A and B in Fig. 9).

The geological studies were compared with computed tsunami characteristics. Figure 10 shows the relationship between the dimensionless collapse speed and the run-up height or distance for all models at three locations. At Nejime, $65 \mathrm{~km}$ from the caldera, a complete sequence of eruptive deposits was found at $20 \mathrm{~m}$ in elevation, suggesting that the tsunami did not inundate at this elevation. A possible tsunami inundation level at this site is less than $20 \mathrm{~m}$. This characteristic can be explained by the slow speed of caldera collapse, $\mathrm{V}_{c} / \sqrt{g h}<0.01$. On the southern coast of the Satsuma Peninsula, $50 \mathrm{~km}$ from the caldera, geological characteristics indicate guidance; (1) tsunami inundated coasts up to 15-20 m above sea level, or (2) an absence of run-up to such a level. Numerical results using the caldera collapse model indicate that the tsunami could inundate the sites where we surveyed outcrops when the dimensionless caldera collapse speed $\left(\mathrm{V}_{c} / \sqrt{g h}\right)$ was more than about 0.003 . For a dimensionless caldera collapse speed of less than 0.001 , the tsunami would have barely inundated any of these coastal areas, if at all. This longer collapse condition might therefore also explain the geological features of these coastal areas.

The source conditions of tsunami generation during the 7.3 ka eruption have been modeled using a range of dimensionless caldera collapse speed, $<0.01$, corresponding with durations of more than $40 \mathrm{~min}$ (deepest collapse model) to more than $20 \mathrm{~min}$ (shallowest collapse model). If the total collapsed volume equals the erupted tephra volume, then the most suitable model may be a deepest collapse one. Since the critical traces of tsunami inundation do not exist in the Satsuma Peninsula, and whether tsunami inundation occurred or not in this area can be limited by a dimensionless caldera collapse speed, 0.003 (1-2 h' duration).

\subsection{Future works}

Geological evidence of tsunami generation in the $7.3 \mathrm{ka}$ eruption was found in submarine sediments in Tachibana Bay (Okamura et al., 2005). In the future, the numerical 

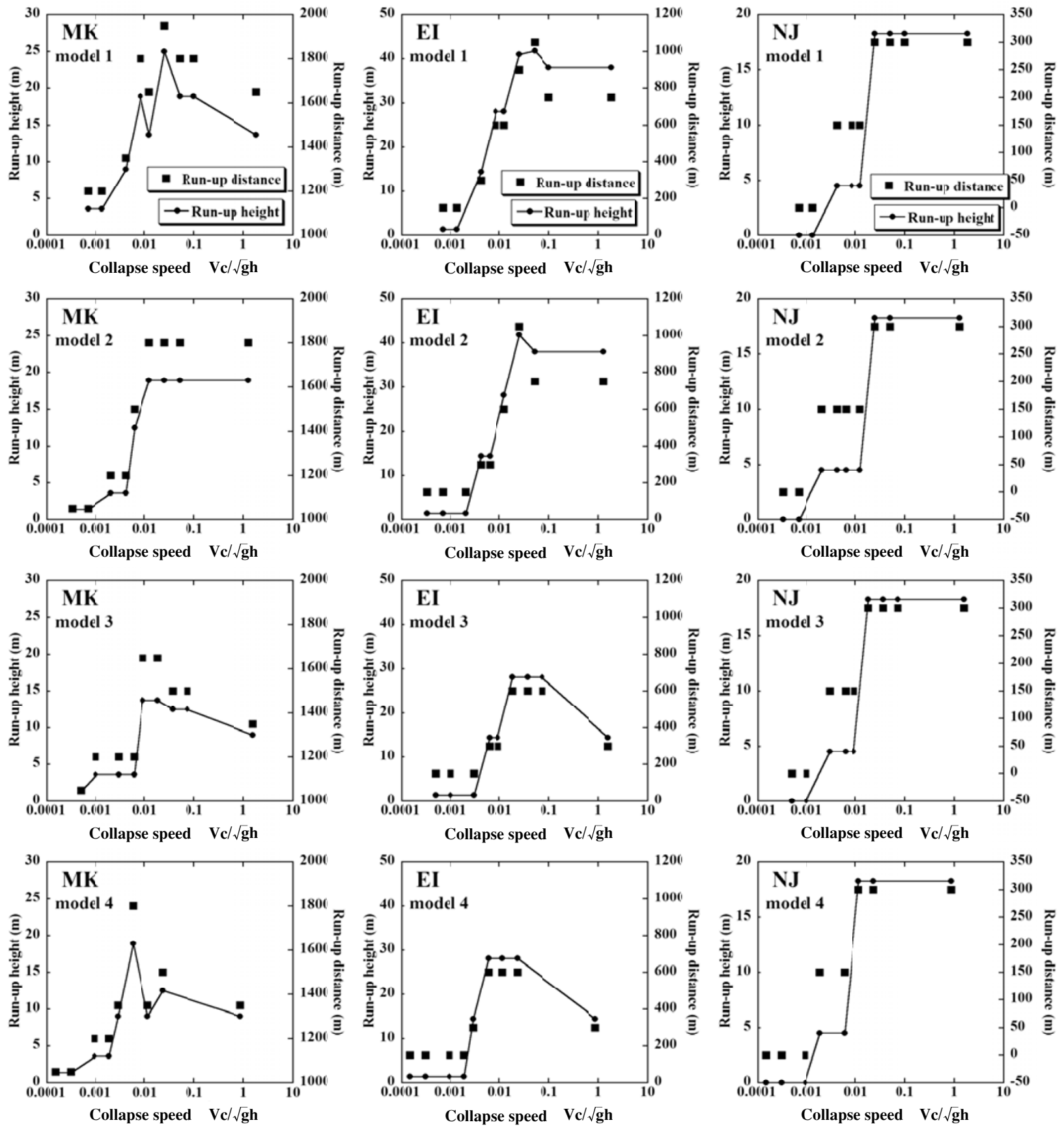

Fig. 10. Run-up heights and distances of the tsunami in relation to the collapse speed at Makurazaki (MK, left), Ei (EI, center), and Nejime (NJ, right) for all collapse models.

models of the tsunami in Tachibana Bay (Figs. 5 and 6) should be used to evaluate whether the near-bottom currents accompanying the tsunami can be sufficient to stir sediment on the sea bottom of the basins, and perhaps reveal the lower limit of the caldera collapse speed. On the other hand, almost all of the near-shore outcrops in the lower elevation at the Satsuma Peninsula have erosion surfaces and lack pumice fallout deposits. These features indicate that tsunamis inundated the area and eroded the deposits, as discussed in Section 7.4. In order to limit the detail process and timing of tsunami inundation, geological characteristics at the coast, such as geomorphology, outcrop distribution, and erosional signatures, should be more investigated.
Moreover, we also need to investigate other tsunami models such as those generated by pyroclastic flow deposition into the sea as a result of column collapses, because these scenarios can also result in serious tsunami damage of coastal areas (Carey et al., 1996, 2000). Rapid transfer of flow momentum into seawater can generate devastating tsunamis that transmit the lethal effects of an eruption over large distances. Evidence from submarine volcaniclastic deposits around the Krakatau caldera indicate that the great 1883 tsunamis were linked, in part, to pyroclastic flow entering the Sunda Straits during the eruption (Carey et al., 2000). In this paper, we cannot suggest a similar model during the $7.3 \mathrm{ka}$ eruption because few detailed studies of 
the submarine deposits around Kikai caldera have been conducted. Although critical evidence of tsunami inundation at the coast in neighboring islands has yet to be investigated, our simulations and results will be useful for investigations of the eruptive sequence of the $7.3 \mathrm{ka}$ eruption.

\section{Conclusion}

This study examined the tsunamis generated by caldera collapse during a $7.3 \mathrm{ka}$ eruption using numerical simulations, and a hypothetical caldera collapsing scale or duration of collapse. Tsunami behavior was determined using non-linear long-wave equations and caldera collapse models showing the difference in geometry between pre- and post- collapse and the duration of collapse. With all models, the computed tsunami heights just outside the caldera were largest when dimensionless collapse speeds $\left(\mathrm{V}_{c} / \sqrt{g h}\right)$ were about 0.01 , and the height substantially decreased with slower speeds (longer collapse durations). A typical waveform shows a negative peak followed by positive peaks. The numerical models indicate that the maximum height of a tsunami and the factors controlling whether inundation occurs in coastal areas is determined by the initial conditions. At three locations along the coast of the Kyushu mainland, the numerical simulations indicate that multiple waves inundated the land in the rapid collapse models. Computed tsunamis were compared with eruptive deposits at three locations. At Nejime, $65 \mathrm{~km}$ from the caldera, no evidence of tsunami inundation was observed. Therefore it is suggested that generated tsunamis were less than $20 \mathrm{~m}$ in height; indicating the upper limit of dimensionless caldera collapse speed was 0.01 , corresponding to a duration of 40 min (deepest collapse model) or $20 \mathrm{~min}$ (shallowest collapse model). On the other hand, on the southern coast of the Satsuma Peninsula, $50 \mathrm{~km}$ from the caldera, no typical tsunami deposits were found. Therefore, it is suggested that tsunamis did not inundate, or that even if tsunamis inundated the area, the traces of tsunami have been eroded by a climactic pyroclastic flow or tsunami itself and they have not been left. Tsunamis may have not supplied materials inland of this area because of few beaches and coral reef, and geomorphological features of the coasts may have also allowed the tsunami to erode the original surface. Based upon the numerical computations, when a dimensionless caldera collapse speed $\left(\mathrm{V}_{c} / \sqrt{g h}\right)$ is more than 0.003 , then a tsunami can inundate this area.

Acknowledgments. The authors would like to thank K. Minoura, T. Kobayashi, H. Naruo, and N. Geshi for critical discussion, and are grateful to A. Goto, T. Miyamoto, and M. Ichihara for logistical advice. We also thank Y. Shigihara and N. Okajima for helpful with mesh-forming and cording, and are grateful to JODC and GSI for providing digital geographical data. We appreciate constructive reviews and comments from B. Keating, C, Mader and Y. Nishimura, and thank the editor A. Takada for efforts in handling the manuscript. This research was supported by a Grant-inaid for Scientific Research entitled 'Dynamics of Volcanic Explosion' from the Ministry of Education, Culture, Sports, Science and Technology, Japan (No. 14080203).

\section{References}

Aoki, K., F. Imamura, and N. Shuto, Proceedings Coastal Engineering Japan, 44, 326-330, 1997 (in Japanese).
Arai, H., T. Oba, H. Kitazato, Y. Horibe, and H. Machida, Late Quaternary tephrochronology and paleo-oceanography of the sediments of the Japan Sea, The Quat. Res. (Daiyonki-Kienkyu), 20, 209-230, 1981 (in Japanese with English abstract).

Aramaki, S., Formation of the Aira caldera, Southern Kyushu, 22,000 years ago, J. Geophys. Res., 89, 8485-8501, 1984.

Aramaki, S. and T. Ui, The Aira and Ata pyroclastic flows and related caldera and depressions in southern Kyushu, Japan, Bull. Volcanol., 29, 29-47, 1966.

Beget, J. E., Volcanic Tsunami, in Encyclopedia of Volcanoes, edited by H. Sigurdsson, Academic Press, pp. 1005-1013, 2000.

Bryant, E., Tsunami - the understand hazard, 320 pp, Cambridge University Press, UK, 2001.

Carey, S., H. Sigurdsson, C. Mandeville, and S. Bronto, Pyroclastic flows and surges over water: an example from the 1883 Krakatau eruption, Bull. Volcanol., 57, 493-511, 1996.

Carey, S., H. Sigurdsson, C. Mandeville, and S. Bronto, Volcanic hazards from pyroclastic flow discharge into the sea: Examples from 1883 eruption of Krakatau, Indonesia, Geol. Soc. Am. Sp. Pap., 345, 1-14, 2000.

Cas, R. A. F. and J. V. Wright, Subaqueous pyroclastic flows and ignimbrites: an assessment, Bull. Volcanol., 53, 357-380, 1991.

Dawson, A. G. and S. Shi, Tsunami deposits, Pure Appl. Geophys., 157, 875-897, 2000.

Francis, P. W., The origin of the 1883 Krakatau tsunamis, J. Volcanol. Geotherm. Res., 25, 349-363, 1985.

Freundt, A. and H. Schmincke, Lithic-enriched segregation bodies in pyroclastic flow deposits of Laacher See volcano (East Eifel, Germany), $J$. Volcanol. Geotherm. Res., 25, 193-224, 1985.

Freundt, A., S. Kutterolf, H. Wehrmann, H-U. Schmincke, and W. Strauch, Eruption of the dacite to andesite zoned Mateare Tephra, and associated tsunamis in Lake Managua, Nicaragua, J. Volcanol. Geotherm. Res., 149, 103-123, 2006.

Gelfenbaum, G. and B. Jaffe, Erosion and sedimentation from the 17 July, 1998 Papua New Guinea Tsunami, Pure. Appl. Geophys., 160, 19691999, 2003.

Goto, C. and Y. Ogawa, Numerical method of tsunami simulation with the Leap-frog scheme, Translated for the TIME Project by N. Shuto, Department of Civil Engineering, Tohoku University, 1992.

Goto, T. and N. Shuto, Proceedings Coastal Engineering Japan, 27, 8084, 1980 (in Japanese).

Gray, J. P. and J. J. Monaghan, Caldera collapse and the generation of waves, Geochem., Geophys. Geosyst., 4(2), 1015, doi:10.1029/ 2002GC000411, 2003.

Ishihara, T., The gravity anomalies on the Kikai caldera and its vicinity, Bull. Geol. Surv. Jap., 28, 575-588, 1976 (in Japanese with English abstract).

Kawanabe, Y. and G. Saito, Volcanic activity of the Satsuma-Iwojima area during the past 6500 years, Earth Planets Space, 54, 295-301, 2002.

Latter, J. H., Tsunamis of volcanic origin: summary of causes, with particular reference to Krakatoa, 1883, Bull. Volcanol., 44, 467-490, 1981.

Lavallee, Y., J. Stix, B. Kennedy, M. Richer, and M. Longpre, Caldera subsidence in areas of variable topographic relief: results from analogue modeling, J. Volcanol. Geotherm. Res., 129, 219-236, 2004.

Machida, H. and F. Arai, Akahoya Ash-A Holocene widespread tephra erupted from the Kikai Caldera, South Kyusyu, Japan, The Quat. Res. (Daiyonki-Kienkyu), 17, 143-163, 1978 (in Japanese with English abstract).

Machida, H. and F. Arai, Atlas of Tephra in and around Japan, 336 pp, University of Tokyo Press, 2003 (in Japanese).

Maeno, F., Dynamics and evolution of a marine caldera-forming eruption at Kikai volcano, Japan, PhD Theses, 150 pp, Tohoku University, 2006.

Maeno, F. and H. Taniguchi, Spatiotemporal evolution of pyroclastic density currents and eruption dynamics during the 7.3 ka marine calderaforming eruption, Kikai Volcano, southern Kyushu, Japan, J. Volcanol. Geotherm. Res., submitted.

Marti, J., G. J. Ablay, L. T. Redshaw, and R. S. J. Sparks, Experimental studies of collapse calderas, J. Geol. Soc. Lond., 151, 1994.

Matsui, T., F. Imamura, E. Tajika, Y. Nakano, and Y. Fujisawa, Generation and propagation of a tsunami from the Cretaceous-Tertiary impact event, Geol. Soc. Am. Sp. Pa., 356, 69-77, 2002.

McCoy, F. W. and G. Heiken, The Late-Bronze Age explosive eruption of Thera (Santorini), Greece: Regional and local effects, Geol. Soc. Am. Sp. Pap., 345, 43-70, 2000.

Minoura, K., F. Imamura, U. Kuran, T. Nakamura, G. A. Papadopoulos, T. Takahashi, and A. C. Yalciner, Discovery of Minoan tsunami deposits, 
Geology, 28, 59-62, 2000.

Nishimura, Y. and N. Miyaji, Tsunami deposits from the 1993 Southwest Hokkaido Earthquake and the 1640 Hokkaido Komagatake Eruption, Northern Japan, Pure Appl. Geophys., 144, 719-733, 1995.

Nomanbhoy, N. and K. Satake, Generation mechanism of tsunamis from the 1883 Krakatau eruption, Geophys. Res. Let., 22, 509-512, 1995.

Okamura, M., H. Matsuoka, and Okamura Makoto Research Committee of Nagasaki Prefecture on Unzen Active Fault System, The evidence of huge Akahoya tsunami recorded in the submarine sediments, 2005 Joint meeting for Earth and Planetary Science, Abstract J027-P025, 2005.

Okuno, M., D. Fukushima, and T. Kobayashi, Tephrochronology in Southern Kyushu, SW Japan: tephra layers for the past 100,000 years, J. Soc. Human History, 12, 9-23, 2000.

Ono, K., T. Soya, and T. Hosono, Geology of the Satsuma-Io-Jima District. Quadrangle Series, Scale 1:50000, Geol. Surv. Japan, 80 pp, 1982 (in Japanese with English Abstract).

Ōki, K., Changes in depositional environments during the post-glacial stage in Kagoshima Bay and Seas around the Northern Part of the Ryukyu Islands, The Quat. Res. (Daiyonki-Kienkyu), 41, 237-250, 2002 (in Japanese with English abstract).

Sato, H. and H. Taniguchi, Relationship between crater size and ejecta volume of recent magmatic and phrato-magmatic eruptions: Implications for energy partitioning, Geophys. Res. Let., 24, 205-208, 1997.

Self, S. and M. R. Rampino, The 1883 eruption of Krakatau, Nature, 294, 699-704, 1981.

Shuto, N., C. Goto, and F. Imamura, Numerical simulation as a means of warning for near-field tsunamis, Coastal Engineering in Japan, 33, 1990.

Sigurdsson, H., S. Carey, C. Mandeville, and S. Bronto, Pyroclastic flows of the 1883 Krakatau Eruption, EOS, 72, 36, 377-392, 1991.

Simkin, T. and R. S. Fiske, Krakatau 1883-eruption and its effects, 464 pp, Smithsonian Institution Press, Washington D.C., 1983

Sullivan, D. G., The discovery of Santorini Minoan tephra in western
Turkey, Nature, 333, 552-554, 1988.

Ui, T., Exceptionally far-reaching, thin pyroclastic flow in Southern Kyushu, Japan, Bull. Volcanol. Soc. Jap. Ser. 2, 18, 153-168, 1973 (in Japanese with English abstract).

Ui, T., H. Metsugi, K. Suzuki, G. P. L. Walker, L. A. McBroome, and M. E. Caress, Flow lineation of Koya low-aspect ratio ignimbrite, south Kyusyu, Japan, A progress report of the U.S.-Japan Cooperative Science Program, 9-12, 1984

Verbeek, R. D. M., Krakatau, Govt. Press, Batavia, 495 pp, 1885.

Walker, G. P. L., L. A. McBroome, and M. E. Caress, Products of the Koya eruption from the Kikai caldera, Japan, A progress report of the U.S.Japan Cooperative Science Program, 4-8, 1984.

Watts, P. and C. F. Waythomas, Theoretical analysis of tsunami generation by pryoclastic flows. J. Geophys. Res., 108, B12, 2563, doi:10.1029/ 2002JB002265, 2003

Waythomas, C. F. and C. A. Neal, Tsunami generation by pyroclastic flow during the 3500-year B.P. caldera-forming eruption of Aniakchak Volcano, Alaska, Bull. Volcanol., 60, 110-124, 1998.

Wilson, C. J. N. and W. Hildreth, The Bishop tuff: New insights from eruptive stratigraphy, J. Geology, 105, 407-439, 1997.

Wolfe, E. W. and R. P. Hoblitt, Overview of the eruptions, in Fire and Mud: Eruptions and Lahars of Mount Pinatubo, Philipines, edited by C. G. Newhall and R. S. Punongbayan, University of Washington Press, Seattle, pp. 3-20, 1996.

Yokoyama, I., A geophysical interpretation of the 1883 Krakatau eruption, J. Volcanol. Geotherm. Res., 9, 359-378, 1981.

Yokoyama, I., A scenario of the 1883 Krakatau tsunami, J. Volcanol. Geotherm. Res., 34, 123-132, 1987.

F. Maeno (e-mail: fmaeno@eri.u-tokyo.ac.jp), F. Imamura, and H Taniguchi 